\title{
Analysis of Rampant Caries Incidence in Kindergarten School 5 - 6 Years Old Kids and A Factor Affecting it in the Working Area of Kaibon Public Health Center in the Madiun District, 2020
}

\author{
Pudji Lestari ${ }^{1}$ and Siti Farida \\ Noor Layla ${ }^{2}$ \\ ${ }^{1}$ Puskesmas Kaibon Kabupaten \\ Madiun \\ ${ }^{2}$ Pascasarjana Magister \\ Kesehatan Institut Ilmu \\ Kesehatan Surya Mitra Husada \\ Indonesia Kediri \\ Email: \\ pudjilestari63171@gmail.com
}

Received : January $13^{\text {th }} 2021$

Accepted : May $4^{\text {th }} 2021$

Published : May 20 2021

\section{ABSTRACT}

The rampant caries is interacting multifactorial disease occurs very quickly, and concerns multiple teeth, and often cause pain. Conditions of caries in children due to unfamiliarity of parents, against the main cause of dental caries. . Caries in the deciduous tooth caused by exposure of teeth by sweet liquids, in the long term. This study aims to analyze the relationship between mother's knowledge, mother's motivation about dental health and consumption patterns of formula milk using a bottle nipples with incidence rampant caries. The research method was analytic observational, with the cross-sectional design. The population of this study are mothers and their children is 538 people. A sampel of 229 people used proportional random sampling technique. Statistic test used is multiple linear regression. The research results show that mother's knowledge, mother's motivation, and consumption patterns formula milk using a bottle nipples has a significant relationship both partially and simultaneously the significance level of caries grade was less than $0,05(\mathrm{p}<0,05)$. Regression models that can be formed are $y$ (incidence of rampant caries) $=4,577-0,785$ mother's knowledge - 0,345 mother's motivation $+0,223$ comsumption pattern. Increased knowledge and motivation of mothers and decreased consumption patterns of milk using bottles will have an effect on reducing the incidence of rampant caries.

Keywords: Mother's knowledge, mothers motivation, consumption patterns formula milk using a bottle nipple, rampant caries

Copyright (C) 2021 IIK STRADA Indonesia All right reserved.

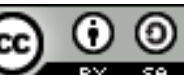

This is an open-acces article distributed under the terms of the Creative Commons Attribution-ShareAlike 4.0 International License.

\section{INTRODUCTION}

Dental caries is a multifactorial disease in the hard tissue of the present become one of the most common problems in Indonesia society, it does not only adults but also occurs in children rates of early childhood dental problems. The highest prevalence of caries cases according to WHO(2017) is in Asia and America reached 60-90\%, where according to 2018 Riskesdas caries cases reached $93 \%$, namely in the age range of 5-6 years. This number is still far from the target of the World Health Organization (WHO) who wants 50\% children aged 56 years to be free of dental caries. In The Minister of Health Regulation No 75 of 2014, describe about the policies the holding of oral health at Public health center is one of them the community dental health efforts through community dental health service activities at pregnant woman, toddlers, children, early childhood education, and the eldery. However, the promotion program activities and early caries prevalence among children 
under five which is managed by health workers, both posyandu as well as in PAUD/TK it is done incidentally. This program is integrated with the SDIDTK (Stimulasi Intervensi Dini Tumbuh kembang)) program which is usually managed by midwife. Dental caries is not one of parameters measured in the treatment of growth and development children. Promotional activities and early caries prevention such as education especially in mothers yet can reach all ages of children who are at risk of caries.

Based on the results of the UKGMD activity we did in Posyandu and Kindergarten in the working area of Kaibon Public Health Center Madiun District, we got the results of the examination in 2 Kindergatens with a total 55 students had a caries 47 children (86\%), only 8 children (14\%) were free of caries. At 3 Posyandu toddler visits were 74 children, 62 children $(84 \%)$ had a caries , only 12 children (16\%) were free of caries. That the caries rate in toddler and pre-school is quite high. Interview with several mothers of toddler, most of them said the tooth phase decidui later will be replaced permanent teeth which is more important. Most of motivation to take care of their children's teeth is lacking and common children are still given formula milk using a bottle nipple.

Therefore, this study aims to analyze the factors that influence numbers insidences of rampant caries in kindergarten children in the working area of Kaibon Public Health center Madiun. The results of this study are expected to provide benefits to Public Health Center as input in determining a policy which can reduce or even prevent rampant caries.

\section{MATERIALS AND METHODS}

This study uses a quantitative research approach. The analysis carried out is analytical. Based on data collection, the study design used an observational approach that was cross sectional. The population in this study were mother and his son who goes to Kindergaten in the working area of the Kaibon Public Health center madiun District, has a secret 5 -6 years totaling 538 five hundred and thirty eight) people. The sample of this study were some of the mother and his son. Sampling was done by proportional random sampling, determine the number of samples for each kindergarten with determine the proportion according to the number of TK under study and the sample is determine. Meanwhile, the determination of the sample size uses the Slovin formula. From the results of the formula, if rounded off, the sample size is 229 respondents.

The Independent variables in this study were mother's knowledge, mother's motivation and patterns consumption of formula milk using a bottle of nipple. Dependent variable is rampant caries incident (Rampant caries Type). The data scale used in this study is a scale ordinal data. The data collecting process in this research consists of two data from primer and secunder. Primary data by distributing of questionnaires and secondary data by using interview or take the existing data. The validity and reliability of the questionnaire were tested in kindergarten the working area of Kaibon Public Health Center was 60 questionaires and data validity testing was carried out with the SPSS software tool using the number (r) Corrected Item Total Results Corelation through the scale menu on the Reliability Analysis option. Reliability testing uses the Alpha Cronbach. regression.

While the test used in this study is the influence test. Statistic test used is multiple linear

\section{RESULTS}

In this study the values of $\mathrm{H}_{0}=0.05$ and $\mathrm{H}_{1}$ are as follows.

a. There is a significant relationship between mother's knowledge on the incidence of rampant caries

b. There is a significant relationship between mother's motivation on the incidence of rampant caries

c. There is a significant relationship between consumption patterns formula milk using a bottle nipples on the incidence of rampant caries

d. There is a significant relationship between mother's knowledge, mother's motivation and consumption patterns formula milk using a bottle nipples on the incidence of rampant caries

From table 1 below can be seen the partial determinants of whether a variable responds to individual significant influence on the incidence rampant caries. There is mother knowledge, mother's motivation, and consumption patterns formula milk using a bottle nipples sig less than 0,05 . The 
conclusion that can be drawn is three variable a partially significant influence for ihe incidence of rampant caries. All variable have a value smaller than 0,05 which means that $\mathrm{H} 0$ is rejected and $\mathrm{h} 1$ is accepted. The regression model that can be formed is y (incidence of caries rampant caries) $=4,577-$ 0,785 mother's knowledge $-0,345$ mother's motivation $+0,223$ milk consumption patterns. This research concludes how increase knowledge and motivation of mother's and decreased milk consumption patterns using a bottle nipple will reduce the incidence of rampant caries.

The influence simultaneously functions to determine the effect of od the variable mother's knowledge, mother's motivation, and consumption patterns formula milk using a bottle nipples toward the incidence of rampant caries jointly. Sig value that is generated from the regressiom analysis to simultaneously as 0,000 . This value is smaller than the error level of recording used $(\alpha)$ namely equal to $0,05(5 \%)$. The conclusion that can be drawn from the value of sig are mother knowledge, mother's motivation, and consumption patterns formula milk using a bottle nipples having a significant influence on the incidence of rampant caries simultaneously, $\mathrm{H}_{0}$ is rejected and $\mathrm{H}_{1}$ is accepted.

From the results of the partial and simultan analysis regression statistical test using SPSS software are as follows.

Tabel 1. Partial analysis Regression Statistic Test Result

\begin{tabular}{|c|c|c|c|c|c|c|c|c|}
\hline \multirow{2}{*}{\multicolumn{2}{|c|}{ Model }} & \multicolumn{2}{|c|}{$\begin{array}{c}\text { Unstandardized } \\
\text { Coefficients }\end{array}$} & \multirow{2}{*}{$\begin{array}{c}\text { Standardized } \\
\text { Coefficients } \\
\text { Beta } \\
\end{array}$} & \multirow[b]{2}{*}{$\mathrm{t}$} & \multirow[b]{2}{*}{ Sig. } & \multicolumn{2}{|c|}{ Collinearity Statistics } \\
\hline & & B & Std. Error & & & & Tolerance & VIF \\
\hline \multirow[t]{4}{*}{1} & (Constant) & 4.577 & .267 & & 17.152 & .000 & & \\
\hline & $\begin{array}{l}\text { Pengetahuan } \\
\text { ibu }\end{array}$ & -.785 & .090 & -.567 & -8.701 & .000 & .373 & 2.681 \\
\hline & Motivasi ibu & -.345 & .098 & -.220 & -3.534 & .000 & .410 & 2.440 \\
\hline & $\begin{array}{l}\text { Pola konsumsi } \\
\text { susu dengan } \\
\text { botol dot }\end{array}$ & .223 & .107 & .097 & 2.088 & .038 & .737 & 1.357 \\
\hline
\end{tabular}

Tabel 2. Multiple Linear Regression Statistic Test result

\begin{tabular}{lrcccl}
\hline \multirow{2}{*}{ Model } & \multicolumn{5}{c}{ ANOVA $^{\mathbf{a}}$} \\
Sum of Squares & df & Mean Square & F & Sig. \\
\hline Regression & 177.200 & 3 & 59.067 & 135.618 & $.000^{\mathrm{b}}$ \\
Residual & 97.996 & 225 & .436 & & \\
Total & 275.197 & 228 & & & \\
\hline
\end{tabular}

\section{DISCUSSION}

\section{Relationship Between Mother's Knowledge about oral health and Incidence Rampant Caries}

In this study, the independent variable of mother's knowledge has an influence on the incidence of rampant caries. Mother Knowledge how to determine the health is very important in funding for the formation of behaviors that support child oral health, so that the chil'd health and mouth can be achievd properly. This is in line with Ghuswan's research (2017) on the relationship between knowledge and maternal actions on the plaque index of children in Ibnu Akbar Kindergarten, Padang City $(\mathrm{p}=0,011)$. It is also supported by Ritasari, 2016 research on relationship between mother's knowledge with the incidence of rampant caries in children at Banjar Negeri village, Way Lima Pesawaran District, offerings that show a significant relationship with the results obtained $p$ value $0,029(\mathrm{p}<0,05)$. Dental disease is also affected by several encouraging factors namely the causal and condasional and one factor that causes dental disease is parents behavior in dental care. This is supported by previous research Ni Wayan Mariati (2015), This results of this research can be seen that it is important to care the child oral health in order to avoid rampant caries. The author assume that the lack of knowledge is due to first parents the figure of a mother does not care about the child's dental health, so mother may not to obtain information related to the child's dental health in order to prevent dental decay incidence. Most parents also give love to their children and enough to give emotional satisfication. 


\section{Relationship Between Mother's Motivation About Oral Health and Incidence Rampant Caries}

In this study,the independent variable of mother's motivation has an influence on the incidence of rampant caries. This result is in accordance with previous research conducted at TK Sinar Matahari by Melisa,dkk (2015). There is relationship between mother's motivation about dental health on Early Childhood Caries on the teeth children aged $3-5$ years can be caused of the strong inner motivation a mother does not object to carry out dental care in children.

Motivation plays an important role for children shape child behavior, especially in preventing dental caries a walk with the opinion presented by Santoso (2017), a person with the right motive has the possibility to mean active in actuality is greater than someone with bad motivation. Rugianto (2017) in his research entitled the relationship between the role of parents with rampant caries in grade III - VI SDN IV Donorejo Sempor District, with the results there is relationship between the role of the parents and the incidence of children's health, where parents who have a good role in health and smoothness will have a bad impact also for children's dental health and the Mukarromah(2018) in his research it is also noted that motivation both intrinsic and extrinsic in relation to dental and oral health problems.

\section{Relationship Between Consumption Patterns Formula Milk Using a Bottle Nipples and Incidence Rampant Caries}

In this research, the independent variable is the pattern of milk consumption using bottle nipples effect on rampant caries. According to Purwaningsih (2016), rampant caries is often seen in children under 6 year, which has the habit of drinking formula milk using bottle nipples. This is similar of Elfi et al (2018) research , The relationship of giving formula milk using bottle nipple with rampant caries in TK Hj Cut Nyak Awan students $(\mathrm{p}=0,000)$. This study is in accordance with that disclosed by Sherit et al (2015) which states that children who consumption formula milk using bottle are a factor predisposes to rampant caries.

\section{Relationship Mother's Knowledge, Mother's Motivation and Consumption Patterns Formula Milk Using a Bottle Nipples and Incidence Rampant Caries}

In this study, we found the three variables simultaneously an effect on the occurrence of rampan caries. The sig value of the regression analysis $0,000(\mathrm{p}<0,05)$. The strength of mother's knowledge will influence the motivation for compassion parenting (Mukaromah,2018). Caries occurs in children because of lack of understanding old age to the main cause occurring, so motivation to prevent it (Rugianto,2017). Caries can be triggered by giving a sweet solution, such as milk, soft drinks using bottles, as well as mother's milk that is given, frequency and intensity is not fast enough (Winda,2015). Increased knowledge and motivation of mothers and decreased consumption patterns of milk using bottles will have an effect on reducing the incidence of rampant caries.

\section{CONCLUSION}

Based on the results of the research that has been carried out and its discussion, the following conclusions can be drawn.

a. There is an influence of mother's knowledge on the incidence of rampant caries in kindergarten school 5-6 years in the working area of Kaibon Public Health Center Madiun District

b. There is an influence of mother's motivation on the incidence of rampant caries in kindergarten school 5-6 years in the working area of Kaibon Public Health Center Madiun District

c. There is an influence of consumption pattern formula milk using a bottle nipples on the incidence of rampant caries in kindergarten school $5-6$ years in the working area of Kaibon Public Health Center Madiun District

d. There is an influence of mother's knowledge, mother's motivation and consumption pattern formula milk using a bottle nipples on the incidence of rampant caries in kindergarten school 5 6 years in the working area of Kaibon Public Health Center Madiun District

Suggestions that can be conveyed based on the results of this study are as follows

a. mother's can increase knowledge and motivation about dental and oral hygiene eliminating bad habbits for their children by not letting them fall asleep with bottle milk, get children used to rinse with water or brush their teeth. 
b. For mother's who work in fulltime or cannot accompany their children those who are still in kindergarten should delegate their duties as mothers in maintain the health of the child's teeth and mouth of the child to the inner child caregiver improving teeth purchasing for feeding formula milk using bottle nipples and activities in the sequence prevent the occurrence of rampant caries.

c. Public health center/health officers provide routine and optimal, perform community empowermet as an extention effort such as training UKGMD cadres and UKGS in order to distribute information related to dental health to the community.

d. Cooperate with school in the care and treatment of dental on preschool children

e. It is necessary to conduct further research on how much influence the practical level affects the behavior of maintaining the health of the teeth and mouth towards the incidence of rampant caries.

\section{ACKNOWLEDGMENTS}

The author would like thank to Alloh SWT, to my husband, children, parents and my beloved sister who have provided good moral and material support so far so that I was able to complete this thesis. Furthermore, thanks and highest appreciation to this thesis supervisor Dr Siti farida Noor Layla, M.Pd, who provided guidance, corrections, and suggestions for the realization of this thesis. Then also thanks to ; Prof. Dr. Sandu Siyoto, S.Sos, S.KM, M.Kes as the rector of IIK STRADA Indonesia Kediri, head and all staff of Kaibon Public Health Center Madiun District, friends of IIK STRADA Indonesia Kediri students, and all parties who have helped the smooth writing of this thesis which cannot be mentioned one by one

\section{CONFLICTS OF INTEREST}

The author does not have a conflict of interest in this study

\section{REFERENCES}

Ani Purwaningsih, Agus Sudaryanto, Arif Widodo. 2016. Pengaruh pemberian susu formula menggunakan botol susu(dot) terhadap kejadian rampan karies pada anak prasekolah di Kelurahan Pabelan http://eprints.ums.ac.id/42385/16/Naskah\%20Ani.pdf

Guswan,dkk. 2017. Hubungan Pengetahuan Dan Tindakan Ibu Terhadap Indeks Plak Anak Tk Ibnu Akbar Jalan Parak Pegambiran Kecamatan Lubuk Begalung Padang. Jurnal Kedokteran Gigi, Volume 29, No 4, Desember 2017

Melisa Anastasia Pranoto, Sandy Cristiono, Resita Indraswary, 2015, Hubungan motivasi ibu tentang kesehatan gigi terhadap early childhood caries pada gigi anak umur 3 - 5 tahun studi terhadap anak Prasekolah di TK Sinar Matahari, , Medali Jurnal Vol 2 Edisi 1

Mukaromah, Z, 2018. Hubungan antara motivasi pemeliharaan kesehatan gigi dan mulut dengan status kebersihan Gigi pada buruh Pabrik Kayu PT Karya cipta Unggul Nusantara Kabupaten Demak. Skripsi. Jurusan keoerawatan Gigi. Poltekkes Kemenkes Semarang.

Ni Wayan Mariati, 2015, Pencegahan dan Perawatan Karies Rampan, Jurnal Biomedik (JBM), Volume 7, Nomor 1, Maret 2015, hlm. 23-28

Ritasari, 2016. Hubungan Pengetahuan ibu dengan Kejadian Karies Gigi pada Anak Di Desa Banjarnegeri Kecamatan WayLima Kabupaten Pesawaran. Wacana Kesehatan Vol.1, No.1, 1-49, Desember 2016

Rugianto, A (2017). Hubungan peran Orang Tua dengan kejadian karies gigi pada siswa Kelas III- VI SDN IV Donorejo kecamatan Sempor. Sekolah Tinggi ilmu kesehatan Muhammadiyah.

Santoso, 2017. Improving Eldery's Dental Hygiene Througt Nursing Home Staff Dental Health Education At The Nursing Home. Jurnal kesehatan

Winda, S. U., Gunawan P., dan Wicaksono D.A. (2015). Gambaran Karies Rampan Pada Siswa Pendidikan Anak Usia Dini Di Desa Pineleng II Indah. Jurnal e-gigi (eg). Januari-Juni. 3(1): 38 . 